\title{
Przyszłość bibliotek i biblioteki przyszłości, czyli trendy kształtujące innowacyjne usługi biblioteczno-informacyjne w bibliotekach akademickich
}

\section{Wstęp}

Tematyka „,bibliotek przyszłości”, „bibliotek nowej generacji” i „,bibliotek innowacyjnych", w szczególności w odniesieniu do bibliotek naukowych i akademickich, poruszana jest w literaturze bibliotekoznawczej od wielu lat. Inspiracją do dyskusji o przyszłości bibliotek były zmiany technologiczne, zmiany w zakresie i sposobie udostępniania zbiorów bibliotecznych, jak również nowoczesne rozwiązania architektoniczne i funkcjonalne. Powstające opracowania i publikacje naukowe skupiały się na konkretnych funkcjach i zadaniach bibliotek oraz dotyczyły wprowadzania w nich innowacyjnych rozwiązań. Podsumowaniem rozważań na temat przyszłości bibliotek uczelni wyższych, ich funkcji oraz roli w zmieniającym się środowisku uczelni jest raport Massachusetts Institute of Technology ${ }^{1}$, opublikowany w 2016 roku, stanowiący punkt odniesienia dla strategii przygotowywanych obecnie przez wiele bibliotek akademickich na całym świecie.

\section{Przyszłość czy śmierć bibliotek?}

Wiele publikacji na temat przyszłości bibliotek skupia się na zagrożeniach, jakie niesie z sobą rozwój rynku e-booków i usług elektronicznych, a nawet sam

${ }^{1}$ Institute-wide Task Force on the Future of Libraries Preliminary Report, Massachusetts Institute of Technology October 24, 2016, https://future-of-libraries.mit.edu/sites/default/files/FutureLibraries-PrelimReport-Final.pdf [dostęp: 20.01.2017]. 
Internet, który jest postrzegany jako potencjalna konkurencja mogąca zagrozić roli biblioteki w gromadzeniu, porządkowaniu i udostępnianiu informacji.

W artykule So Now What?: The Future for Librarians ${ }^{2}$ Steve Coffman pisze o tym, w jaki sposób biblioteki i bibliotekarze powinni bronić swojej pozycji oraz jakimi sposobami utwierdzać przede wszystkim siebie w przekonaniu, że ich pozycja nie jest zupełnie przegrana $\mathrm{w}$ starciu $\mathrm{z}$ komercyjnymi dostawcami literatury, wiedzy i informacji. Wiele rozważań w literaturze branżowej ma podobny wydźwięk i wydawać by się mogło, że biblioteki stają się niepotrzebne, a ich podstawowym zadaniem w najbliższych latach będzie ochrona własnej tożsamości i bytu.

Dyskusja ta przypomina dyskusję sprzed ponad dwudziestu lat, kiedy zaczęły upowszechniać się publikacje elektroniczne i przepowiadano „śmierć książki”. W 1992 roku na pierwszej stronie „New York Times Book Review” ukazał się przełomowy esej Roberta Coovera. Tytułowe stwierdzenie The End of Books ${ }^{3}$ stało się punktem odniesienia dla wielu badaczy literatury, pisarzy i wydawców. Co więcej, tekst ten spowodował, że literatura, przeznaczona do odczytywania na ekranie komputera, zaistniała w świadomości szerszego grona odbiorców i zyskała na popularności. W 2008 roku na polskim rynku ukazała się książka Łukasza Gołębiewskiego Śmierć ksiązki. No future book, która była pierwszą w Polsce próbą całościowego ujęcia problematyki digitalizacji literatury. Gołębiewski przepowiadał nie tylko koniec książki, lecz głosił przede wszystkim nadejście nowego typu czytelnika - wychowanego przed monitorem komputera, przyzwyczajonego do innej struktury zdań, do innego układu tekstu, nielinearnego wykładu, piktogramów, emotikonów; użytkownika, który swobodnie korzysta z własności intelektualnej, który używa cyberjęzyka. Opisywany użytkownik nie jest nazywany przez Gołębiewskiego „czytelnikiem”, ale raczej „czytaczem” i „szperaczem”. Poddaje on kulturę druku ciężkiej próbie, ale również wyznacza nowy kierunek jej rozwoju ${ }^{4}$.

Podobnie jak „śmierć książki” nie nastąpiła, tak i nie należy wyczekiwać końca bibliotek i skupiać się na opracowywaniu strategii obrony ich pozycji. Rolą bibliotekarzy powinno być formułowanie nowej definicji biblioteki, odpowiadającej zmieniającym się potrzebom użytkowników i uwzględniającej nowe trendy i technologie kształtujące współczesny rynek książki i informacji.

${ }^{2}$ S. Coffman, So Now What?: The Future for Librarians, „Online Searcher, Information Discovery, Technology, Strategies” 37, nr 1 - January/February 2013, http://www.infotoday.com/ OnlineSearcher/Articles/Features/So-Now-What-The-Future-for-Librarians-86856.shtml [dostęp: 12.01.2017].

${ }^{3}$ R. Coover, The End of Books, „The New York Times on the Web. Books” June 21, 1992, www.nytimes.com/books/98/09/27/specials/coover-end.html [dostęp: 12.01.2017].

${ }^{4}$ Ł. Gołębiewski, Śmierć książki. No future book, Warszawa 2008. 


\section{Biblioteka innowacyjna — próba definicji}

Kierunki rozwoju bibliotek zawsze wyznaczały tak zwane biblioteki innowacyjne będące pionierami w tworzeniu i wdrażaniu nowatorskich rozwiązań. Biblioteki innowacyjne nie tylko obserwują nowe trendy i szukają rozwiązań na miarę potrzeb użytkowników, lecz również dzielą się wiedzą i rozwiązaniami ze środowiskiem bibliotekarzy na całym świecie, przejmując rolę liderów w kształtowaniu nowoczesnego bibliotekarstwa przyszłości.

Na początek należy sprecyzować, jaką bibliotekę można określić mianem biblioteki innowacyjnej. Samo zjawisko innowacji jest ściśle związane z pojęciem zmiany, postępu, reformy. Za innowacje uważa się fakty, procesy i zjawiska o charakterze technicznym, organizacyjnym, społecznym czy psychologicznym. Niedługa tradycja badań nad innowacjami, jak i odmienność ujęć teoretycznych sprawiają, że pojmowanie innowacji jest zróżnicowane i nie do końca jednoznacznie sprecyzowane.

Pojęcie innowacji wprowadził do nauk ekonomicznych Joseph Alois Schumpeter, który rozumiał innowacje jako tworzenie zmian fundamentalnych lub radykalnych, obejmujących transformację nowej idei albo technologicznego wynalazku w rynkowy produkt lub proces ${ }^{5}$. Według Podręcznika Oslo (Oslo Manual — międzynarodowy podręcznik metodologiczny badań statystycznych innowacji, zalecany w krajach $\mathrm{OECD}^{6}$ i Unii Europejskiej) innowacja to wdrożenie nowego lub istotnie ulepszonego produktu, procesu, nowej metody marketingu lub nowej metody organizacji w zakresie praktyk biznesowych, organizacji miejsca pracy bądź relacji ze środowiskiem zewnętrznym ${ }^{7}$.

Zgodnie z zaprezentowanymi założeniami innowacyjna biblioteka uczelniana powinna nie tylko wdrażać nowe technologie i innowacyjne rozwiązania już powstałe, lecz również je tworzyć. Powinna także kreować nowoczesne usługi i formy organizacyjne w taki sposób, by zaspokajać potrzeby środowiska akademickiego.

${ }^{5}$ E. Stawasz, G. Niedbalska, Innowacje, [w:] Stownik Innowacji - Leksykon haset. Portal Innowacji [portal], http://www.pi.gov.pl/parp/chapter_96055.asp?soid=677964766D394262AB915FB61187C008 [dostęp: 12.03.2017].

${ }^{6}$ OECD (Organisation for Economic Cooperation and Development — Organizacja Współpracy Gospodarczej i Rozwoju).

${ }^{7}$ Podręcznik Oslo. Zasady gromadzenia i interpretacji danych dotyczacych innowacji. Wydanie Trzecie, Warszawa 2006, http://www.uwm.edu.pl/ciitt/wp-content/uploads/2013/10/Podrecznik-OSLO-MANUAL1.pdf [dostęp: 12.12. 2016]. 


\section{Biblioteki i innowacje w literaturze przedmiotu}

Piśmiennictwo na temat innowacji w bibliotekach akademickich w 2015 roku przeanalizował Curtis Brundy w artykule Academic Libraries and Innovation: A Literature Review ${ }^{8}$, próbując określić, w jaki sposób innowacje są przyjmowane i realizowane przez biblioteki. Autor analizował piśmiennictwo w języku angielskim obejmujące zasięgiem chronologicznym 33 lata (od 1981 roku). Uzasadniając podjęcie tego tematu, Brundy podkreślał, że biblioteki akademickie stoją obecnie przed bezprecedensowym wyzwaniem, kiedy innowacyjność stała się koniecznością. Dzieje się to w warunkach stale malejących budżetów i rosnących kosztów oraz zmieniających się potrzeb użytkowników.

$\mathrm{Na}$ podstawie analizy literatury przedmiotu, Brundy wyróżnił dwie najpotężniejsze siły motywujące biblioteki do innowacyjności. Pierwsza z nich to coraz mniejsze nakłady finansowe na biblioteki, a druga to szeroko rozumiany postęp technologiczny. Tymczasem powszechna w wielu bibliotekach tendencja do ujednolicania struktur oraz procesów organizacyjnych, według przeprowadzonych analiz, minimalizuje napływ nowej wiedzy i zmniejsza tempo innowacji, zwłaszcza radykalnych ${ }^{9}$.

Jak pisze Brundy w swoim opracowaniu, budżety bibliotek akademickich stale maleją. Badanie przeprowadzone przez Stowarzyszenie Bibliotek Amerykańskich (ALA - American Library Association) w 2014 roku wykazało, że budżet biblioteki w roku 1982 stanowił średnio 3,7\% budżetu uczelni, tymczasem w roku 2011 było to już zaledwie 1,8\%. Analizie tej poddano czterdzieści bibliotek członkowskich ALA. Były to zarówno biblioteki największych ośrodków naukowych w Stanach Zjednoczonych, takich jak Harvard czy Yale, jak również inne, mniejsze biblioteki uczelni publicznych. Na spadek wysokości budżetów bibliotek akademickich miały wpływ również katastrofy ekonomiczne, takie jak kryzys gospodarczy w latach 2007-2008.

Brundy powołuje się między innymi na rozprawę doktorską Ronalda C. Jantza z 2013 roku, która koncentruje się na zagadnieniu innowacyjności bibliotek akademickich. Jako czynniki wpływające na rozwój innowacji Jantz wskazuje między innymi: kluczową rolę kadry kierowniczej biblioteki (zakres, w jakim zespół liderów biblioteki wspiera innowacje poprzez alokację zasobów, współpracę, budowanie zespołu i wymianę informacji), zróżnicowanie strukturalne i organizacyjne, wpływ i poparcie środowiska zewnętrznego (dostępność zasobów, a także niepewność, zakres i tempo zmian zachodzących w środowisku zewnętrznym) oraz „orientację dwukierunkową” (ang. ambidextrous orientation), czyli zdolność biblioteki do realizowania zarówno tak zwanych przyrostowych (ang. incremental), jak i radykalnych innowacji ${ }^{10}$.

${ }^{8}$ C. Brundy, Academic Libraries and Innovation: A Literature Review, „Journal of Library Innovation" 6, Issue 1, 2015, http://www.libraryinnovation.org/article/view/420/625 [dostęp: 12.12.2016].

${ }^{9}$ Ibidem.

${ }^{10}$ R.C. Jantz, Incremental and radical innovations in research libraries: An exploratory examination regarding the effects of ambidexterity, organizational structure, leadership and contextual 


\section{Biblioteki przyszłości - przegląd trendów kluczowych dla bibliotek kolejnej generacji}

Thomas Frey, prowadzący blog „Futurist Speaker”, w swoim wpisie zatytułowanym The Future of Libraries ${ }^{11}$ opisuje czynniki, które w najbliższej przyszłości będą miały wpływ na zadania i role bibliotek.

Wymienia on dziesięć kluczowych trendów wpływających na rozwój kolejnej generacji bibliotek. Pokazują one nie tylko różnorodność czynników wynikających z rozwoju technologii w samych bibliotekach, ale przede wszystkim te mające wpływ na mentalność i oczekiwania użytkowników ${ }^{12}$.

Trend 1. Systemy komunikacyjne stale zmieniają się pod wpływem tego, jak w społeczeństwie ewoluują sposoby dostępu do informacji. — Zarówno książka drukowana, jak i pismo samo w sobie są technologiami, których żywotności i trwania nikt nie jest w stanie zagwarantować. Nie jesteśmy w stanie poznać „ostatecznej” formy komunikacji, którą ludzkość będzie posługiwała się zawsze. Systemy łączności ewoluowały bardzo szybko, od wynalezienia telegrafu w 1844 roku poprzez telefon (1876), radio (1896), faks (1935), telewizję (1939), pierwszy komputer ENIAC (1946), e-mail (1965), telefon komórkowy (1973), wreszcie World Wide Web (1989) i przeglądarkę internetową (1992), aż po Google (1996) oraz Facebook (2004) i inne formy mediów społecznościowych. Nikt tak naprawdę nie wie, jakie będą kanały i sposoby komunikacji przyszłości.

Trend 2. Wszystkie technologie kończą się i dezaktualizują. - Technologie dziś powszechnie stosowane, w przyszłości zostaną zastąpione przez inne. Zmieniają się formaty multimedialne, nośniki, sposoby komunikacji i przesyłania danych.

Trend 3. Miniaturyzacja nośników danych. — Standardów przechowywania informacji nie jesteśmy w stanie obecnie zdefiniować jednoznacznie, ze względu na postępującą miniaturyzację nośników i zmiany formatów danych.

Trend 4. Technologie wyszukiwania informacji stają się coraz bardziej skomplikowane. - Współczesna technologia wyszukiwania informacji opiera się na wyszukiwaniu tekstowym, które może być rozszerzone o wersje językowe, niektóre formy obrazu, dźwięku i wideo. Jednak następna generacja technologii wyszukiwania będzie obejmować również zdolność do wyszukiwania takich atrybutów, jak smak, zapach, konsystencja, masa, gęstość i objętość. Wyzwaniem dla bibliotekarzy będzie zdolność do przeprowadzania coraz bardziej skomplikowa-

factors, The State University of New Jersey-New Brunswick, ProQuest Dissertations Publishing, 2013 [rozprawa doktorska], dostępny w ProQuest Dissertations and Theses (3597757) [dostęp: 20.12.2016].

${ }^{11}$ T. Frey, The Future of Libraries, Futurist Speaker [blog], November 2nd, 2006, http://www. futuristspeaker.com/future-scenarios/the-future-of-libraries/ [dostęp: 20.01.2017].

12 Zestawienia stanowią streszczenia trendów opisywanych w cytowanej literaturze. 
nych wyszukiwań, ponieważ w większości przypadków użytkownicy informacji, niemający niezbędnych umiejętności ani czasu, będą poszukiwali pomocy kompetentnego specjalisty.

Trend 5. Kompresja czasu i przeciążenie danymi. - Tempo życia sprawia, że wymagania względem dostępu do informacji również się zmieniają. Przeciętny użytkownik biblioteki oczekuje dostępu do informacji w coraz krótszym czasie, a jednocześnie $w$ coraz bardziej przystępnej formie.

Trend 6. Przejście na technologie werbalne. — Zmienia się również sposób dostępu do informacji. Ze względu na postęp technologiczny użytkownicy komputerów prawdopodobnie nie będą w przyszłości korzystali z klawiatury, wydając na przykład jedynie komendy głosowe. Komputery staną się bardziej podobne do człowieka. Zyskają osobowość oraz inne cechy, które użytkownikowi dadzą poczucie przebywania w jednym pomieszczeniu z innymi ludźmi.

Trend 7. Zapotrzebowanie na globalną informację rośnie w postępie geometrycznym. - Poznanie i zrozumienie kultury reszty świata stanowi klucz do powstawania globalnych społeczeństw przyszłości. Wzrost globalnego przepływu ludności, legalnych i nielegalnych imigrantów oraz globalizacja rynków pracy powoduje, że wiedza na temat innych kultur i krajów, w których przedsiębiorcy chcą zakładać własne firmy, a pracownicy chcą zaistnieć na rynku pracy, definiuje szczególne potrzeby informacyjne i kolejną nową rolę bibliotek.

Trend 8. Rozwój globalnych systemów. - Globalne systemy obejmują obecnie między innymi: handel międzynarodowy, globalny transport morski, systemy metryczne, globalne serwisy informacyjne, systemy pocztowe, strefy czasowe, transport lotniczy i globalny obrót giełdowy, a także system GPS i Internet. Będą one rozwijać się i powstawać w różnych innych nowych obszarach. Biblioteki będą odgrywać kluczową rolę w rozwoju systemów globalnych, ponieważ będą one obciążone archiwizacją i rozpowszechnianiem fundamentalnych informacji.

Trend 9. Przechodzenie z gospodarki opartej na produktach do gospodarki opartej na doświadczeniach. - Powstaną nowe sposoby prezentacji i interakcji z informacjami zawartymi w nowych i nietypowych formatach. Użytkownicy bibliotek będą oczekiwali od nich dostosowania usług i zasobów do własnych potrzeb i doświadczeń.

Trend 10. Biblioteki będą ewoluowały z centrów informacji i danych do centrów kultury. - Biblioteka przyszłości to taka, która sięga do ducha wspólnoty i społecznych priorytetów oraz zapewnia środki ich wsparcia. Nowoczesne centra kulturalne to muzea, teatry i instytucje edukacyjne. Biblioteki przyszłości mogą obejmować wszystkie ich funkcje, zabezpieczając potrzeby lokalnych społeczności.

Tendencje opisane przez Freya wskazują na rolę technologii w kształtowaniu się nowych systemów komunikacji oraz nowych usług informacyjno-bibliotecznych. Nie negują przyszłej roli bibliotek w tych systemach, wręcz przeciwnie wskazują obszary, w których biblioteki powinny rozwijać swoje kompetencje, by wychodzić naprzeciw oczekiwaniom użytkowników. 
Próby określenia kierunków rozwoju tak zwanych bibliotek przyszłości podejmowały również instytucje naukowe. W wielu wypadkach obserwacje i przepowiadane scenariusze pokrywają się z sobą, w niektórych analizach jednak obserwatorzy zwracają uwagę na różne aspekty pracy bibliotek i procesy zachodzące w ich otoczeniu, dzięki czemu można stworzyć przegląd przewidywanych trendów.

W 2015 roku na Uniwersytecie ARUP w Londynie powstał raport Future Libraries. Workshops Summary and Emerging Insights ${ }^{13}$. Raport ten również opisuje trendy i zjawiska, które zdaniem autorów będą miały wpływ na przyszłość bibliotek publicznych, akademickich i korporacyjnych. Jest to wynik analizy prowadzonej podczas cyklu warsztatów odbywających się w Londynie, Melbourne, San Francisco i Sydney, z udziałem ekspertów w zakresie projektowania i zarządzania bibliotekami.

Według autorów raportu ARUP kluczowymi trendami, które wpływają na przyszłą rolę i kształt bibliotek, są czynniki zarówno technologiczne, jak i społeczne:

Trend 1. Rozpad danych. - Ciągły i nieustający postęp technologiczny spowodował przyrost ilości danych w zróżnicowanej gamie formatów i zapisanych na różnych nośnikach. W związku ze zmianą technologii oraz wypieraniem starszych rozwiązań przez nowe formaty i nośniki, wiele danych ginie, uniemożliwiając przekazywanie tak zgromadzonej wiedzy kolejnym pokoleniom.

Trend 2. Alternatywne finansowanie. - Chociaż zmieniające się role bibliotek wymagają ciągłości ich pracy oraz stałego rozwoju kompetencji, stale ograniczane budżety bibliotek są ich największym problemem i zagrożeniem. Coraz więcej z nich sięga w związku z tym po alternatywne źródła finansowania.

Trend 3. Wykorzystanie mediów społecznościowych. - Biblioteki wykorzystują media społecznościowe do interakcji zarówno z użytkownikami, jak również ze swoimi organizatorami i potencjalnymi donatorami.

Trend 4. Otwarty dostęp i prawa autorskie. - Upowszechniający się ruch Open Access oraz dążenie do szerszego i nieograniczonego udostępniania twórczości naukowej powodują, że pracownicy naukowi, autorzy i użytkownicy wymagają coraz więcej wsparcia w zrozumieniu i respektowaniu przepisów prawa własności intelektualnej.

Trend 5. Przeciążenie informacyjne. - Powstające każdego dnia ogromne ilości danych mogą ograniczać ludzką percepcję, decyzyjność i produktywność. Rolą bibliotekarzy jest pomoc użytkownikowi w wyborze, porządkowaniu i ocenie jakości informacji.

Trend 6. Inteligentne systemy i robotyzacja. - W związku z tendencją do zmniejszania się powierzchni przeznaczonej do przechowywania zbiorów inteli-

${ }^{13}$ Future Libraries. Workshops Summary and Emerging Insights, ARUP July 2015, http:// publications.arup.com/publications/f/future_libraries [dostęp: 12.01.2017]. 
gentne systemy zarządzania i zautomatyzowane systemy przechowywania będą zyskiwać na znaczeniu.

Trend 7. Uniwersalny, bezstronny i bezpieczny dostęp do wiedzy. - Wiedza stanowi formę bogactwa. Uniwersalny dostęp do informacji i wiedzy jest szczególnie ważny w krajach rozwijających się, które mają ograniczony dostęp do technologii cyfrowych. Jednocześnie w dostępie do wiedzy użytkownik liczy na jej wysoką jakość oraz bezpieczeństwo.

Trend 8. Centra kulturalno-usługowe. — Biblioteki stają się miejscami przeznaczonymi do wspierania rozwoju kultury i innowacyjności lokalnego społeczeństwa. Przyjmują dodatkowe role, aby nie tylko świadczyć usługi w zakresie dostępu do informacji, lecz tworzyć atmosferę sprzyjającą kreatywności i rozwojowi.

Trend 9. Zaangażowanie społeczne. — Wśród zadań bibliotek, zwłaszcza publicznych, upatruje się często poszukiwania sposobów utrzymania i rozwoju lokalnej tożsamości. Współpraca z lokalnymi społecznościami pomaga katalizować ten proces.

Trend 10. Modele nauczania. - Tanie i powszechne technologie cyfrowe zapewniają większe możliwości w zakresie nauczania, uczenia się, prowadzenia badań i zarządzania organizacjami. Kształcenie ustawiczne jest dziś uznanym i powszechnym zjawiskiem. Rola biblioteki w tym procesie może ewoluować od samego wspierania uczenia się oraz nauczania do zwiększania możliwości w obszarze kształcenia poprzez zapewnienie niezbędnych zasobów i narzędzi.

Trend 11. Mobilny styl życia. — Nomadyczny i mobilny styl życia współczesnego społeczeństwa definiuje styl pracy i sposób dostępu do informacji. Inteligentne urządzenia i otwarte przestrzenie definiują również sposób gromadzenia i udostępniania informacji.

W podsumowaniu raportu ARUP przyszła rola bibliotek przedstawiona jest optymistycznie. Pomimo powszechnego dostępu do informacji, oferowanego przez inne technologie, biblioteki, zdaniem autorów raportu, pozostaną miejscem, w którym użytkownicy będą poszukiwali bezpośredniego kontaktu z książką oraz wsparcia bibliotekarza w wyszukiwaniu i ocenie jakości informacji. Podkreślają oni również, że biblioteki będą definiowały swoje przestrzenie w taki sposób, aby zapewnić użytkownikom sprzyjające kreatywności środowisko pracy. Adaptacyjność i elastyczność będą kluczem do projektowania pomieszczeń i usług, które odpowiadają potrzebom i oczekiwaniom użytkowników ${ }^{14}$.

W 2014 roku pod auspicjami American Library Association powstało Centrum Przyszłości Bibliotek (Center for the Future of Libraries), które określa między innymi bieżące trendy i problemy oraz wspiera innowacyjność i rozwój biblio-

\footnotetext{
${ }^{14}$ Ibidem.
} 
tek ${ }^{15}$. Na stronie Centrum sukcesywnie gromadzone są opisy bieżących tendencji w rozwoju bibliotek i ich działalności informacyjnej. Zostały one zorganizowane w siedmiu kategoriach — społeczeństwo, technologie, edukacja, środowisko, polityka, ekonomia i warunki demograficzne.

Każdy artykuł, opisujący konkretny trend, skonstruowany jest w podobny sposób: zawiera genezę i ogólny zarys problemu, a także wyjaśnienie, dlaczego ma on znaczenie dla bibliotek. Wpis uzupełniony jest bibliografią przedmiotową $^{16}$. Tendencje te mają raczej charakter pewnego słownika pojęć i zjawisk, które w mniejszym lub większym stopniu wpływają na postawy i oczekiwania użytkowników bibliotek. Oprócz tego swoistego słownika trendów na stronie Centrum dostępne są również publikacje, blog oraz kontakty do ekspertów oferujących wsparcie dla bibliotek.

\section{Przyszłość bibliotek według raportu Massachusetts Institute of Technology}

W październiku 2015 roku rektor Massachusetts Institute of Technology, Martin A. Schmidt, poprosił Chris Bourg, dyrektor bibliotek MIT, o powołanie i pokierowanie zespołem zadaniowym do spraw przyszłości bibliotek (Task Force on the Future of Libraries). W swoim komunikacie do społeczności akademickiej zachęcił pracowników i studentów Instytutu do dzielenia się z zespołem swoimi spostrzeżeniami oraz podkreślił wagę tego przedsięwzięcia. W skład zespołu weszli przedstawiciele środowiska naukowego z kilku wydziałów Instytutu, specjaliści od zarządzania i organizacji, studenci oraz bibliotekarze ${ }^{17}$.

Zadaniem powołanego zespołu było określenie, w jakim kierunku biblioteki MIT powinny ewoluować w zakresie tworzenia, gromadzenia i rozpowszechniania wiedzy, aby pełnić rolę lidera bibliotek naukowych w kwestii innowacji.

Założeniem, jakie przyjęto w Instytucie Technologicznym Massachusetts było, aby uczelnia i jej biblioteki odgrywały wiodącą rolę w rozwoju otwartych,

${ }^{15}$ Center for the Future of Libraries, Library of the Future [strona domowa], http://www.ala. org/transforminglibraries/future [dostęp: 12.01.2017].

16 Trendy opisane na stronie Centrum to: starzenie się społeczeństwa, anonimizacja, oznaczenia cyfrowe, dochód podstawowy (narodowy), zbiorowe oddziaływanie, zdalne nauczanie, wszechobecność danych, cyfrowi tubylcy (pokolenie cyfrowe), drony, dorastanie młodzieży, fandom, fast casual, odwrócone nauczanie, grywalizacja, technologie dotykowe, nierówność dochodów, Internet rzeczy, ruch Maker, polityki prywatności, odporność, roboty, ekonomia dzielenia się, małe formy, Unplugged, urbanizacja.

${ }^{17}$ Skład zespołu dostępny jest w załączniku nr 2 do raportu: Institute-wide Task Force on the Future of Libraries Preliminary Report (Appendix 2. Task Force Members), Massachusetts Institute of Technology October 24, 2016, https://future-of-libraries.mit.edu/sites/default/files/FutureLibraries-PrelimReport-Final.pdf [dostęp: 20.01.2017]. 
skutecznych i sprawiedliwych modeli zapewniających najbardziej wydajne środowisko oraz narzędzia do wsparcia edukacji i procesów badawczych. Ponadto podkreślano, że istotne jest, aby materiały badawcze i edukacyjne MIT były udostępniane jak najszerszej publiczności, a także, by środowisko naukowe skupione wokół Instytutu miało dostęp do najlepszych narzędzi i zasobów niezbędnych do realizowania zadań dydaktycznych i badawczych.

Efektem ponad rocznej pracy trzydziestoosobowego zespołu był raport o przyszłości bibliotek akademickich oraz ich roli we wspieraniu działalności naukowo-badawczej - Institute-wide Task Force on the Future of Libraries. Preliminary Report. October 24, $2016^{18}$ ogłoszony w październiku 2016 roku.

W raporcie nakreślona została wizja biblioteki jako otwartej, globalnej platformy zakorzenionej we wspólnych wartościach i misji, wspieranej przez innowacyjne podejście. Wizja biblioteki przyszłości określa ją jako otwartą i interaktywną bibliotekę wiedzy, która tworzy globalną sieć ${ }^{19}$.

Grupa zadaniowa obejmowała zespoły robocze, których celem była odpowiedź na pytania dotyczące roli bibliotek przyszłości w następujących obszarach:

- społeczność i relacje (Community and Relationships);

- odkrywanie i użytkowanie (Discovery and Use);

— zarządzanie i zrównoważony rozwój (Stewardship and Sustainability);

- badania i rozwój (Research and Development).

W efekcie powstała wizja biblioteki przyszłości jako globalnej platformy opartej na czterech filarach:

1. relacje z lokalnymi i globalnymi społecznościami;

2. odkrywanie i wykorzystanie informacji;

3. zarządzanie zasobami naukowymi i dziedzictwem;

4. zaangażowanie w badania i rozwój biblioteki przyszłości.

Wizję tę opisuje dziesięć rekomendacji pogrupowanych według wymienionych obszarów:

Rekomendacja 1: Biblioteki MIT muszą stanowić bibliotekę globalną, służącą uczelni i użytkownikom. Powinny one wyobrazić sobie społeczności, którym służą, jako koncentryczne kręgi, począwszy od najbliższego kręgu obecnych studentów i pracowników Instytutu, do coraz szerszych kręgów: naukowców współpracujących, absolwentów, słuchaczy kursów elearningowych, lokalnej społeczności i szeroko rozumianej globalnej wspólnoty naukowej.

Rekomendacja 2: Grupa zadaniowa rekomenduje Instytutowi utworzenie nowej grupy planistycznej, której zadaniem będzie stworzenie koncepcji przebudowy przestrzeni bibliotecznych MIT według wizji i zaleceń wynikających $\mathrm{z}$ raportu.

${ }^{18}$ Institute-wide Task Force on the Future of Libraries Preliminary Report, Massachusetts Institute of Technology October 24, 2016, https://future-of-libraries.mit.edu/sites/default/files/FutureLibraries-PrelimReport-Final.pdf [dostęp: 20.01.2017].

${ }^{19}$ Ibidem. 
Rekomendacja 3: W ramach wspierania misji badawczo-dydaktycznej biblioteki zapewnią odpowiednie wsparcie, w celu wyposażenia członków społeczności MIT w kluczowe umiejętności, pozwalające na krytyczne i efektywne wykorzystanie informacji. Będą ponadto pomagały kształcić umiejętności niezbędne do tworzenia nowej wiedzy oraz platform, systemów i sieci służących do jej udostępniania.

Rekomendacja 4: W celu wsparcia misji MIT oraz wartości wynikających z otwartości i zakresu usług, biblioteki MIT powinny być zaufanym kanałem rozpowszechniania wyników badań Instytutu w skali globalnej.

Rekomendacja 5: Biblioteki MIT zapewnią kompleksowy dostęp do kolekcji treści cyfrowych oraz rozpoczną projekt digitalizacji wielu swoich analogowych kolekcji.

Rekomendacja 6: Poprzez interdyscyplinarne partnerstwa wewnętrzne i zewnętrzne biblioteki powinny generować otwarte i interoperacyjne platformy treści, pozwalające tworzyć, wykorzystywać, rozpowszechniać, zabezpieczać i promować nowe metody zarządzania informacją.

Rekomendacja 7: Grupa zadaniowa rekomenduje utworzenie nowego zespołu zadaniowego w obszarze Open Access. Jego rolą byłby przegląd funkcjonującej polityki otwartego dostępu i sformułowanie na jej podstawie nowych zaleceń i dobrych praktyk w celu jak najszerszego rozpowszechniania wyników badań prowadzonych w Instytucie.

Rekomendacja 8: Biblioteki MIT mają tworzyć trwałe, zaufane repozytorium wyników prac badawczych oraz określających je metadanych, prowadząc jednocześnie prace mające na celu gromadzenie i przechowywanie dokumentów związanych z historią i tradycją Instytutu.

Rekomendacja 9: Biblioteki MIT powinny nadal aktywnie angażować się w globalne projekty oraz przewodzić im, na rzecz wypracowania efektywnych systemów i modeli tworzenia, gromadzenia i zabezpieczania wyników badań.

Rekomendacja 10: Zespół zadaniowy rekomenduje Instytutowi utworzenie komórki badawczej w zakresie nauki o informacji i komunikacji naukowej z siedzibą w bibliotekach MIT w celu prowadzenia badań naukowych dotyczących wyzwań, relacji, odkryć i dobrych praktyk związanych z działalnością informacyjną i komunikacją naukową.

Zespół zadaniowy w swoim raporcie podkreśla ponadto konieczność rozwoju bibliotek MIT w kierunku biblioteki interaktywnej, zaangażowanej, reagującej i współpracującej. Powodzenie tej misji przyniosłoby wymierny efekt w postaci utworzenia centrum kompetencji i wiedzy fachowej, mającej realny wpływ na przyspieszenie rozwoju nauki i możliwości rozwiązywania najważniejszych światowych wyzwań i problemów. 


\section{Podsumowanie}

Raport MIT nie jest pierwszą czy jedyną tego typu inicjatywą na uczelniach amerykańskich. W 2013 roku raport na temat przyszłości biblioteki uniwersyteckiej opublikowała również specjalna komisja powołana na Uniwersytecie Berkeley $\mathrm{w}$ Kalifornii ${ }^{20}$. Autorzy raportu Berkeley podkreślają między innymi, że w ciągu najbliższych dwudziestu lat biblioteka, w rozumieniu zarówno miejsca, jak i usług, będzie miała coraz większe znaczenie dla badawczych i dydaktycznych zadań uczelni. Jako konkretne działania, mające na celu utrzymanie wysokiej pozycji i jakości świadczonych usług biblioteki Uniwersytetu Berkeley, wskazują oni sukcesywne zwiększanie budżetu biblioteki oraz liczby wykwalifikowanych pracowników.

Przeprowadzona analiza literatury poświęconej przyszłości bibliotek i tworzonym w nich innowacjom pozwala stwierdzić, że przyszłe zadania bibliotek wynikać będą ze zmieniających się oczekiwań użytkowników oraz trendów technologicznych i społecznych. Największym zagrożeniem rozwoju innowacyjności bibliotek naukowych jest stałe zmniejszanie się środków finansowanych przeznaczonych na ich działalność i rozwój. Chociaż przyszłość bibliotek i ich rola są od wielu lat stale w centrum zainteresowania badaczy z obszaru bibliotekoznawstwa i nauki o informacji, obecnie szybciej i intensywniej muszą one dostosowywać swoją rolę i zadania do zmieniającej się rzeczywistości i technologii. Niewłaściwą strategię stanowi natomiast przyjmowanie postawy obronnej i skupianie się na udowadnianiu tego, że biblioteki w ogóle są potrzebne. O tym, jak ważne jest śledzenie aktualnych trendów i dostosowywanie oferty bibliotek do oczekiwań użytkowników i zmieniających się realiów, świadczy zakres wyzwań, jakie stawiają przed bibliotekami, zwłaszcza naukowymi i akademickimi, władze instytucji naukowo-badawczych, którym biblioteki służą. Świadomość, jaką w tym zakresie przejawiają władze największych światowych instytucji badawczych, takich jak amerykański Instytut Technologiczny Massachusetts, uwidacznia się w działaniach mających na celu przekształcanie bibliotek w centra informacji i wsparcia w zakresie komunikacji naukowej i zarządzania informacją. To właśnie w bibliotekach powstają uczelniane repozytoria, nie tylko publikacji, lecz także danych badawczych. Biblioteki przejmują również role centrów kompetencji i wsparcia w zakresie otwartego dostępu do zasobów nauki, praw autorskich i własności intelektualnej, a także wspierania procesów kształcenia, zarówno stacjonarnego, jak i na odległość. Kierunki rozwoju bibliotekarstwa przyszłości będą wyznaczały biblioteki innowacyjne, świadome swojej roli i możliwości wpływania na sukces naukowy swoich macierzystych uczelni. Będą one wyznaczały nowe zadania, obszary współpracy oraz stanowiły centra dla kształtującej się globalnej biblioteki służącej ogólnoświatowej społeczności naukowej.

${ }^{20}$ Report of the Commission on the Future of the UC Berkeley Library, Berkeley University of California, October 2013, http://evcp.berkeley.edu/sites/.../FINAL_CFUCBL_report_10.16.13. pdf [dostęp: 28.01.2017]. 


\section{Bibliografia}

Brundy C., Academic Libraries and Innovation: A Literature Review, „Journal of Library Innovation” 6, 2015, Issue 1, http://www.libraryinnovation.org/article/view/420/625 [dostęp: 12.12.2016].

Center for the Future of Libraries, Library of the Future [strona domowa], http://www.ala.org/ transforminglibraries/future [dostęp: 12.01.2017].

Coffman S., So Now What?: The Future for Librarians, „Online Searcher, Information Discovery, Technology, Strategies" 37, Number 1 - January/February 2013, http://www.infotoday.com/ OnlineSearcher/Articles/Features/So-Now-What-The-Future-for-Librarians-86856.shtml [dostęp: 12.01.2017].

Coover R., The End of Books, „The New York Times on the Web. Books” June 21, 1992, www.nytimes. com/books/98/09/27/specials/coover-end.html [dostęp: 12.01.2017].

Frey T., The Future of Libraries, Futurist Speaker [blog], November 2nd, 2006, http://www.futuristspeaker.com/future-scenarios/the-future-of-libraries/ [dostęp: 20.01.2017].

Future Libraries. Workshops Summary and Emerging Insights, ARUP July 2015, http://publications. arup.com/publications/f/future_libraries [dostęp: 12.01.2017].

Gołębiewski Ł., Śmierć książki. No future book, Warszawa 2008.

Institute-wide Task Force on the Future of Libraries Preliminary Report, Massachusetts Institute of Technology October 24, 2016, https://future-of-libraries.mit.edu/sites/default/files/FutureLibraries-PrelimReport-Final.pdf [dostęp: 20.01.2017].

Jantz R.C., Incremental and radical innovations in research libraries: An exploratory examination regarding the effects of ambidexterity, organizational structure, leadership and contextual factors, The State University of New Jersey - New Brunswick, ProQuest Dissertations Publishing, 2013 [rozprawa doktorska], dostępny w ProQuest Dissertations and Theses (3597757) [dostęp: 20.12.2016].

Podręcznik Oslo. Zasady gromadzenia i interpretacji danych dotyczacych innowacji. Wydanie trzecie. Warszawa 2006, http://www.uwm.edu.pl/ciitt/wp-content/uploads/2013/10/Podrecznik-OSLOMANUAL1.pdf [dostęp: 12.12. 2016].

Report of the Commission on the Future of the UC Berkeley Library, Berkeley University of California, October 2013, http://evcp.berkeley.edu/sites/.../FINAL_CFUCBL_report_10.16.13.pdf [dostęp: 28.01.2017].

Stawasz E., Niedbalska G., Innowacje, [w:] Stownik Innowacji - Leksykon haset. Portal Innowacji [portal], http://www.pi.gov.pl/parp/chapter_96055.asp?soid=677964766D394262AB915FB61187C008 [dostęp: 12.03.2017]. 


\title{
The future of libraries and the libraries of the future - new trends shaping innovative library and information services in academic libraries
}

\begin{abstract}
Summary
The development of libraries and their services depends on technological development, the users' needs and socioeconomic conditions. Innovative libraries as the pioneers in implementing cuttingedge solutions lead the way in showing the direction of changes. The innovations implemented by libraries are a response to global trends, changing needs and users' expectations. The article presents an overview of factors and phenomena which inspire libraries to use cutting-edge solutions and create new initiatives that will define the roles and responsibilities of the libraries of the future regarding research libraries, with particular reference to academic libraries. The analyses were based on the research institutions and libraries' reports which define the trends and recommendations in shaping the structures and tasks of the innovative libraries. The main document of this type is the report prepared by Massachusetts Institute of Technology (MIT) defining the library of the future as an open and interactive library of knowledge which create a global network. The analyzed documents describe the research tasks of libraries and highlight the development of research and academic libraries' responsibilities towards transforming libraries into cultural centres. The documents also emphasize the libraries' social role not only in the research and academic community, but also at the local and national levels.
\end{abstract}

KEYWORDS: innovations, academic libraries, trends in library development, future libraries 